\title{
Ecotoxicity and Fate of Silver Nanomaterial In An Outdoor Lysimeter Study After Twofold Application By Sewage Sludge
}

\author{
Martin Hoppe ( $\square$ martin.hoppe@bgr.de) \\ BGR https://orcid.org/0000-0002-1938-760X \\ Jan Köser \\ BGR \\ Kerstin Hund-Rinke \\ Fraunhofer Institute for Molecular Biology and Applied Ecology ScreeningPort: Fraunhofer-Institut fur Translationale Medizin und Pharmakologie \\ ITMP Drug Discovery Research ScreeningPort \\ Karsten Schlich \\ Fraunhofer Institute for Molecular Biology and Applied Ecology ScreeningPort: Fraunhofer-Institut fur Translationale Medizin und Pharmakologie \\ ITMP Drug Discovery Research ScreeningPort
}

\section{Research Article}

Keywords: Silver nanomaterial, silver nitrate, plant uptake, long-term experiment, ammonium oxidizing bacteria, soil, outdoor lysimeter

Posted Date: October 28th, 2021

DOI: https://doi.org/10.21203/rs.3.rs-991428/v1

License: (c) (1) This work is licensed under a Creative Commons Attribution 4.0 International License. Read Full License

Version of Record: A version of this preprint was published at Ecotoxicology on March 9th, 2022. See the published version at https://doi.org/10.1007/s10646-022-02529-3. 


\section{Abstract}

The increasing use of antibacterial silver nanomaterials (AgNMs) in consumer products leads to their release into sewers. High amounts of AgNMs become retained in sewage sludge, which causes their accumulation in agricultural soils when sewage sludge is applied as fertilizer. This increase in silver arouses concerns about toxicity to soil organisms and transfer within trophic levels. Long-term field studies simulating the sewage sludge pathway to soils are sparse, and the effects of a second sewage sludge application are unknown.

In this perennial field lysimeter study, a twofold application of AgNM (NM-300K, $2+3 \mathrm{mg} \mathrm{Ag} / \mathrm{kg}$ dry matter soil (DMS)) and a onefold application of $\mathrm{AgNO}_{3}(2 \mathrm{mg} \mathrm{Ag} / \mathrm{kg}$ DMS) by sewage sludge to the uppermost $20 \mathrm{~cm}$ of the soil (Cambisol) were applied. The response of microorganisms to the applications was determined by measuring the inhibition of ammonium-oxidizing bacteria (AOB). Silver concentrations in soil, leachates, and crops were measured after acid digestion by inductively coupled plasma mass spectrometry (ICP-MS).

Almost no vertical Ag translocation to deeper soil layers and negligible Ag release to leachates suggest that soil is a large sink for AgNM and $\mathrm{AgNO}_{3}$. For $\mathrm{AgNM}$, an increase in toxicity to $\mathrm{AOB}$ was shown after the second sewage sludge application. The application of $\mathrm{AgNO}_{3}$ resulted in long-term toxicity comparable to the toxicity of AgNM. Low root uptake from both $\mathrm{AgNM}$ - and $\mathrm{AgNO}_{3}$-spiked lysimeters to crops indicates their incomplete immobilization, which is why food chain uptake cannot completely be excluded. However, the root-shoot barrier for wheat $(9.8 \rightarrow 0.1 \mathrm{mg} / \mathrm{kg})$ and skin body barrier for sugar beets $(1.0 \rightarrow 0.2 \mathrm{mg} / \mathrm{kg})$ will further reduce the accumulation within trophic levels. Moreover, the applied AgNM concentrations were above the predicted environmental concentrations (PECs), which is why the root uptake might be negligible in agricultural practice.

\section{Highlights}

- In a perennial field study, most of the applied $\mathrm{AgNM}$ and $\mathrm{Ag}^{+}$remained immobile in soil

- The release of $\mathrm{Ag}$ to the leachates was very low (<176 ng/L)

- Low, continuous, species-specific transfer of $\mathrm{AgNM}$ and $\mathrm{Ag}^{+}$from soil to wheat and sugar beet

- Constant and comparable inhibition of AOB by AgNM and $\mathrm{Ag}^{+}$

- Second sewage sludge application (AgNM) after four years leads to increased toxicity

\section{Introduction}

Silver nanomaterials (AgNMs) are one of the most widely used nanomaterials (NMs) in various consumer products because of their antimicrobial properties (Benn et al. 2010). The production and use of AgNM-containing products lead to increased AgNM emissions into wastewater (Bundschuh et al. 2018). Thus, the entry of AgNM into wastewater treatment plants (WWTPs) is inevitable (Kaegi et al. 2013). High amounts of AgNM become retained in sewage sludge (Westerhoff and Nowak 2013; Schlich et al. 2013). Therefore, the transfer of sewage sludge to agricultural soils is one of the most important NM pathways into the environment (Tourinho et al. 2012; Pan and Xing 2012). Several short-term studies showed a rather high retention of AgNM for most agricultural soils, which is why soils were considered a large sink for AgNM (Pan and Xing 2012; Cornelis et al. 2014; Hoppe et al. 2014; Hoppe et al. 2015; Wang et al. 2018).

The accumulation of potentially toxic AgNM in soil leads to concerns about the soil bacterial community (Forstner et al. 2020). Ecotoxicological experiments with AgNM under standardized conditions confirmed that pure AgNM affects the biomass content by substrate-induced respiration, the enzyme activity of soils and ammonia oxidizing bacteria (Hänsch and Emmerling 2010; Schlich and Hund-Rinke 2015). Partial sulfidation of AgNM was found in experiments with raw sewage sludge (Kaegi et al. 2013). This process might decrease the toxicity of AgNM and potentially limit their environmental impact (Levard et al. 2012). Otherwise, AgNM introduced to a model sewage treatment plant, applied to soil via sewage sludge and tested after 100-140 d, remained as toxic toward soil microorganisms as freshly prepared AgNM applied to soil and tested after $28 \mathrm{~d}$ (Schlich et al. 2013). This was also demonstrated in studies in which AgNM was first sulfidized (Kraas et al. (2017); Schlich et al. (2018). In addition, Forstner et al. (2020) showed for a test duration of $90 \mathrm{~d}$ that the effects of processed AgNM on soil bacterial communities were larger and more persistent than those of fresh AgNM, silver sulfide nanomaterial $\left(\mathrm{Ag}_{2} \mathrm{~S}-\mathrm{NM}\right)$, and silver nitrate $\left(\mathrm{AgNO}_{3}\right)$. In general, Spurgeon et al. (2020) addressed the urgent need for long-term studies about the toxicity of NM.

Metal-based NMs can cross the root barrier and translocate through the vascular system into various tissues, which is controlled by NM physicochemical characteristics, plant species and the rate of transpiration (Ruotolo et al. 2018). Schlich et al. (2018) applied different NMs (AgNM, $\mathrm{Ag}_{2} \mathrm{~S}-\mathrm{NM}$ ) and $\mathrm{AgNO}_{3}$ to soils by sewage sludge and obtained Ag uptake to oat (Avena sativa L.), whereby the shoots contained less Ag than the roots. In general, the accumulation of AgNM in soil leads to major concern about the food chain due to modifications in the nutrient values of food crops and transfer within trophic levels (Gardea-Torresdey et al. 2014). However, long-term studies that elucidate the fate and toxicity of AgNM and silver ions $\left(\mathrm{Ag}^{+}\right)$under realistic environmental conditions are still very sparse (Schlich et al. 2017). Yang et al. (2020) investigated the fate of biosolid-borne $\mathrm{Ag}$ in an outdoor field study and found $\mathrm{Ag}$ accumulation in the soil and a very low $\mathrm{Ag}(<1 \%$ o) uptake to crops. Outdoor lysimeter experiments confirmed that AgNM was associated with soil colloids and showed a very low breakthrough $(<0.1 \%)$ to undisturbed loamy sandy 
arable soil (Makselon et al. 2018). Low release of Ag from AgNM-spiked sandy soil to the leachates of a field lysimeter was also found in our previous study, which also exhibited toxicity to ammonium oxidizing bacteria (AOB) and Ag root uptake to wheat and canola (Schlich et al. 2017). Despite the fact that knowledge about the fate and impact of AgNM in soil has constantly grown in the last decade, Courtois et al. (2019) reviewed that much remains unclear about the ecotoxicology of Ag species in soil, especially with respect to a possible entry to the trophic food chain by accumulation in plant tissues. In particular, AgNM root uptake to agricultural crops such as wheat and canola (Schlich et al. 2017) raised concern about AgNM uptake to sugar beets, which might pave the pathway into the human food chain. Moreover, the AgNM fate and toxicity after repetitive AgNM-containing sludge application to agricultural soil under field conditions are still unknown.

This long-term study was conceptualized to address these knowledge gaps about AgNM fate and toxicity after the second application (first application 2014, second application 2018) of AgNM-spiked and unspiked sewage sludge to soil. In addition, the study also aimed to investigate the fate and effect of $\mathrm{AgNO}_{3}$ as an ionic Ag source in the field lysimeter experiment, which was not part of the first study published in 2017 (Schlich et al., 2017). This study investigates (i) the vertical translocation of $\mathrm{AgNM}$ and $\mathrm{AgNO}_{3}$ in the uppermost $40 \mathrm{~cm}$ of the lysimeter, (ii) the release of $\mathrm{Ag}$ to the leachates, (iii) the uptake of $\mathrm{Ag}$ to wheat roots and sugar beets, and (iv) the inhibition of AOB.

Therefore, soil samples were digested with aqua regia, plant samples were digested in nitric acid $\left(\mathrm{HNO}_{3}\right)$, and water samples were filtered and acidified with $\mathrm{HNO}_{3}$. Afterward, Ag concentrations in the samples were measured with inductively coupled plasma optical emission spectroscopy (ICP-OES) and inductively coupled plasma mass spectrometry (ICP-MS). Following ISO 15685 (2012), the inhibition of AOB was measured to determine the response of microorganisms to the application of $\mathrm{AgNM}$ and $\mathrm{AgNO}_{3}$ to the soil (Cambisol).

\section{Material And Methods}

\subsection{Experimental setup}

The general experimental setup regarding the lysimeters, the used soil and the amount of AgNM applied via sewage sludge in 2014 have been published in Schlich et al. (2017). In the following section, all methods are briefly described. The focus in the current study was on the second application of $\mathrm{AgNM}$ via sewage sludge to the existing lysimeters and the preparation of new lysimeters with $\mathrm{AgNO}_{3}$ or controls with pure sewage sludge without $\mathrm{AgNM}$ or $\mathrm{AgNO}_{3}$ application.

\subsubsection{Soil}

The experiments were conducted using a reference soil (RefeSol $01 \mathrm{~A}, \mathrm{pH}_{\mathrm{CaCl} 2}=5.61, \mathrm{C}_{\text {org }}=9.3 \mathrm{~g} / \mathrm{kg}$, clay content $=61 \mathrm{~g} / \mathrm{kg}$ ), which was classified as Cambisol (Ad-hoc-AG Boden, 2006). For detailed physicochemical properties, refer to Table S1. The soil was selected as reference soils by the German Federal Environment Agency, and it matches the properties stated in various OECD terrestrial ecotoxicological guidelines (e.g., tests with plants and soil microflora).

\subsubsection{Silver nanomaterials and silver nitrate}

A colloidal silver dispersion (NM-300K), with a nominal silver content of $10 \%(\mathrm{w} / \mathrm{w})$ and a transmission electron microscope diameter smaller than $20 \mathrm{~nm}$, was used as AgNM. The particles are dispersed in a mixture of stabilizing agents (NM-300K DIS) comprising 4\% (w/w) each of polyoxyethylene glycerol trioleate and polyoxyethylene sorbitan monolaurate according to Klein et al. (2011). Silver nitrate from Merck (Merck KGaA, Darmstadt, Germany) was used as a pure material in the crystalline structure.

\subsubsection{Sewage sludge}

Sewage sludge fed municipal sewage was freshly gathered at the WWTP of Schmallenberg (Germany). The sewage sludge met the requirements of the German Sewage Sludge Ordinance (AbfKlärV, 1992) regarding the metal content (lead, cadmium, chromium, copper, nickel, mercury, zinc) of sewage sludge used as fertilizer on agricultural land. For the application of $\mathrm{AgNM}$ and $\mathrm{AgNO}_{3}$, sewage sludge was sieved to particles smaller than 2 $\mathrm{mm}$ and then stored in a vessel under permanent moderate stirring and aeration $(2.5 \mathrm{mg} \mathrm{O} / \mathrm{L})$.

$\mathrm{AgNM}$ and $\mathrm{AgNO}_{3}$ were spiked into sewage sludge by a ratio dry matter of sewage sludge sufficient to receive the desired nominal concentrations after application via sewage sludge. After the addition of either $\mathrm{AgNM}$ or $\mathrm{AgNO}_{3}$ into sewage sludge, the sludge remained in the vessel for another $16 \mathrm{~h}$ under aeration and moderate stirring to allow transformation reactions of the $\mathrm{AgNM}$ or $\mathrm{AgNO}_{3}$ with the surrounding media and the interaction with the sewage sludge. To separate water and sewage sludge, the same flocculant as 2014 (0.2\% cationic polyacrylamide solution, Sedifloc 154 , Kemira Germany GmbH, Frankfurt) was applied.

\subsubsection{Setup of lysimeters}

The experiment is an extension of the lysimeter experiment described by Schlich et al. (2017). In the first part of the experiment, AgNM was incorporated into soil via sewage sludge. Over a period of three years, both the effect of AgNM on soil microorganisms and their fate in the 
uppermost $40 \mathrm{~cm}$ of the lysimeter and in leachate were investigated. In the second part of the experiment, sewage sludge (with and without AgNM) was again applied to the already existing lysimeters to investigate the influence of repeated AgNM input via sewage sludge on the fate and effect of AgNM. In addition, the fate and effect of $\mathrm{AgNO}_{3}$ in a lysimeter experiment was considered in comparison to AgNM.

Control lysimeters (unspiked sewage sludge, L1, L27) and lysimeters with AgNM concentrations of 2 (L2) and 8 (L6) mg Ag/kg dry matter soil (DMS) were tested in the first part of the experiment (Schlich et al. 2017). Again, $1.67 \mathrm{~g}$ dry matter sewage sludge/kg DMS was applied to the lysimeters (L1, L2, L6) in May 2018. In L2, AgNM was mixed to achieve a nominal concentration of $8 \mathrm{mg} / \mathrm{kg}$ DMS. Here, the aim was to investigate whether a comparable effect could be achieved as it was observed for lysimeter 6 ( $8 \mathrm{mg} \mathrm{Ag} / \mathrm{kg}$ DMS) in the first part of the experiment. In addition, pure sewage sludge was applied to L6 with $8 \mathrm{mg} \mathrm{Ag} / \mathrm{kg}$ DMS to observe whether the detected strong inhibition further increased over time or if it reached a steady state or even decreased. In addition, a new lysimeter experiment was initiated to obtain data on the comparability of effects observed due to $\mathrm{AgNO}_{3}$ and $\mathrm{AgNM}$. For the control (L27), only sewage sludge was applied to the soil, and for L28, a concentration of $2 \mathrm{mg} \mathrm{Ag/kg}$ DMS was introduced into the soil by $\mathrm{AgNO}_{3}$-spiked sewage sludge.

The artificially filled lysimeters $(0.9 \times 0.9 \times 0.9 \mathrm{~m} ; \sim 1 \mathrm{t}$ DMS $)$ are cubic shaped and made of high-grade stainless steel. The volume of approximately $1 \mathrm{~m}^{3}$ of the soil presents a homogeneous and integrating system. For microbial determinations, samples can be collected at distinct locations to consider potential inhomogeneity. Since the aim of the study was to investigate the effects of $\mathrm{AgNM}$ and $\mathrm{AgNO}_{3}$ applied via sewage sludge to soil on soil microorganisms, no lysimeter containing only soil was included. There was no effect on the soil microflora (ammonia oxidizing bacteria and microbial respiration) due to NM-300K DIS (Schlich et al. 2013), the dispersant of NM-300K. Therefore, no separate lysimeter containing only the dispersing agent has been conducted.

According to the German sewage sludge ordinance (AbfKlärV, 1992), sludge can be applied on argicultural land at an amount of $5 \mathrm{t} /$ ha in three years. Following current practice, it was assumed that the complete amount of sewage sludge would be applied at once. In addition, a soil depth of $20 \mathrm{~cm}$ (in accordance with agricultural practice) and a soil bulk density of $1.5 \mathrm{~g} / \mathrm{cm}^{3}$ (OECD Guideline 216, 2000; OECD Guideline 217, 2000) were assumed for the calculation of the amount of sewage sludge that could be applied to the soil.

Sewage sludge was applied as described in Schlich et al. (2017). Briefly, first sewage sludge was mixed over 30 minutes with $25 \mathrm{~kg}$ DMS, taken from the top layer $(20 \mathrm{~cm})$ of the lysimeters, to receive a homogeneous mixture of soil and sewage sludge containing either $\mathrm{AgNM}$ or $\mathrm{AgNO}_{3}$. Afterward, the mixture of soil-sewage sludge was spread on the top of the soil in the lysimeters and mixed into the top $20 \mathrm{~cm}$ with a spade. After the second application of sewage sludge in the lysimeters with AgNM (L1, L2, L6), the pH of the soil decreased (pH<5). Therefore, in November 2018, 75 $\mathrm{g}$ of $\mathrm{CaO}$ (Quicklime for soil improvement; purity $82 \%$ (CaO + MgO), Zement- und Kalkwerke Otterbein GmbH + Co. KG, Großenlüder-Müs, Germany) was added to each lysimeter containing AgNM and the control lysimeter to increase the pH values. No CaO was added to the new lysimeters (L27,

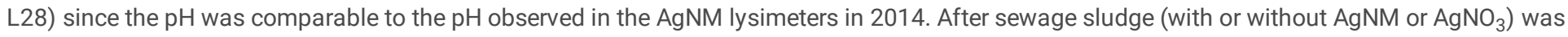
incorporated into the soil (May 2018), leachate was sampled, but there was no sampling of the soil to allow a new equilibrium to be established.

In June 2018, summer wheat (Triticum aestivum 'Tybalt A', Saaten Union GmbH Isernhagen, Germany) was sown followed by black fallow land from September 2018 to May 2019. The seeds were untreated for experimental purposes. Afterward, sugar beet (Hordeum vulgare SYTypee, Syngenta, Maintal, Germany) was sown in May 2019 and harvested in September 2019. Plants were observed on a weekly basis and irrigated with the same amount (10-30 L) of tap water in dry periods (L1, 2, 6, 27 and 28: July 18 until August 3rd, 2018).

At harvest of the wheat, approximately $50 \%$ of the plants were taken, including their roots. The remaining plants were cut $5 \mathrm{~cm}$ above the ground. The roots remained in the soil to prevent the removal of $\mathrm{AgNM}$ or $\mathrm{AgNO}_{3}$ accumulated in the roots. The harvested wheat plants were divided into roots and shoots before they were stored at $-21^{\circ} \mathrm{C}$ until analysis. The sugar beets were collected, and the soil was stripped away. The sugar beets were stored at $4^{\circ} \mathrm{C}$ in a refrigerator until analysis. After harvesting, five soil samples per lysimeter were taken using a soil sampler (Pürkhauer drilling stick) for the top $40 \mathrm{~cm}$ and divided in steps of $10 \mathrm{~cm}$.

The leachate of each lysimeter was permanently collected, and the volume was determined. Water samples were taken regularly, filtered ( $0.45 \mu \mathrm{m}$ polyethersulfon syringe filter, VWR International $\mathrm{GmbH}$, Langenfeld, Germany), and preserved with $100 \mu \mathrm{l}$ of $69 \% \mathrm{HNO}_{3}$ suprapur (Carl Roth $\mathrm{GmbH}+$ Co. KG, Karlsruhe, Germany) before analysis.

\subsubsection{Ecotoxicological test system}

The results of the first part of the experiment (Schlich et al. 2017) showed that AOB (potential ammonium oxidation, ISO Guideline 15685, 2012) were more strongly inhibited by AgNM than the substrate induced respiration (SIR, OECD 217, 2000). For this reason, in the second part of the experiment, we focused on the effect of $\mathrm{AgNM}$ and $\mathrm{AgNO}_{3}$ on $\mathrm{AOB}$. In accordance with ISO 15685 (ISO Guideline 15685, 2012), the nitrite concentration was determined by a short-term potential ammonium oxidation test to observe the effects on soil nitrifying bacteria. The objective of ISO 15685 (2012) is to measure the ammonia oxidation potential, which provides an indication of the size of the ammonia oxidizing bacterial population.

2.1.6 Climate and soil conditions 
The average monthly rainfall was between 40 and $199 \mathrm{~mm}$, and the average monthly temperature was between $-2.9^{\circ} \mathrm{C}$ and $17.5^{\circ} \mathrm{C}$ from June 2018 until October 2019. In L1, 2 and 6, the measured pH from June 2018 (addition of sewage sludge) until November 2018 (liming with CaO) was between 4.4 and 4.8 and increased to a maximum pH of between 6.1-6.6 in May 2019 (Table S2). In August 2019, the measured pH values were between 5.0 and 5.3. In the new lysimeters ( $\mathrm{L} 27$ and 28) with a control and $\mathrm{AgNO}_{3}$, the pH was between 5.1 and 6.0 from June 2018 until May 2019 and decreased to a final pH from 4.9 to 5.0, which was comparable with L1, 2 and 6, until August 2018.

\subsection{Analytics}

\subsubsection{Soil, plant material, leachate}

The soil pH was measured in $0.01 \mathrm{~mol} / \mathrm{L} \mathrm{CaCl}_{2}$ (Th. Geyer, Renningen, Germay) after $24 \mathrm{~h}$ of extraction using a inoLab pH 720 (WTW GmbH, Weilheim, Germany). According to DIN EN 16174:2012-11 (2012), aqua regia digestion (ARD) was applied to the ground soil samples. The Agtotal concentration after ARD was labeled as $\mathrm{Ag}_{\mathrm{ARD}}$. According to Lowry et al. (2012), the dried and ground plant materials were digested with $\mathrm{HNO}_{3}(65$ $\%$, Suprapur, Merck, Darmstadt, Germany). The volume of concentrated $\mathrm{HNO}_{3}$ was increased from $1.5 \mathrm{ml}$ to $4 \mathrm{ml}$ to enable a complete dissolution of the plant tissues. The $\mathrm{Ag}$ concentration after $\mathrm{HNO}_{3}$ digestion was labeled $\mathrm{Ag}_{\mathrm{HNO}}$. According to DIN 38402-11:2009-02 (2009), the leachates were filtered ( $0.45 \mu \mathrm{m}$, Graphic Controls, Buffallo, NY, USA) and acidified (69\%, $\mathrm{HNO}_{3}$, Suprapur, Carl Roth GmbH \& Co. KG, Karlsruhe, Germany) immediately after sampling. The measured $\mathrm{Ag}$ concentrations of the leachates were labeled $\mathrm{Ag}_{\mathrm{DIN} 38402}$. Inductively coupled mass spectrometry (ICP-MS, 7700 Series, Agilent, Santa Clara, California, USA) and inductively coupled optical emission spectroscopy (ICP-OES, Ciros Vision, Spectro, Kleve, Germany) were used to determine the Ag concentrations in the leachates and in the digested soil and plant materials.

\subsection{Statistics}

Statistical analysis was conducted using ToxRatPro v3.3.0 software for ecotoxicity response analysis (ToxRat Solutions GmbH, Alsdorf, Germany) and SPSS 22.0.0.0 (IBM Corp., Armonk, USA). For the microbial tests, Student's t-test for homogeneous variances (one sided, * $p<0.05$; ** $p<0.01$; $\left.{ }^{* * \star} p<0.001\right)$ was performed after proving homogeneity of variances tested by Levene's test $(a=0.05)$. In Figure 4 , significant $p$ values are marked with asterisks.

The statistical analysis regarding the $\mathrm{Ag}_{\mathrm{DIN} 38402}$ concentrations in the leachates of the lysimeters was executed with IBM SPSS Statistics. The measurement data were not normally distributed, which is why the nonparametric Mann-Whitney $U$ test was applied. This test was used to assess whether the distributions of the $\mathrm{Ag}_{\text {DIN38402 }}$ concentrations from the AgNM-spiked and $\mathrm{AgNO}_{3}$-spiked lysimeters (L2, L6, L28) were equal to the control lysimeters (L1, L27), which is the null hypothesis. All deviations $( \pm)$ of measurement data given in the text represent the standard deviations of at least three replicates.

\section{Results And Discussion}

\subsection{Silver concentrations in the lysimeters soil}

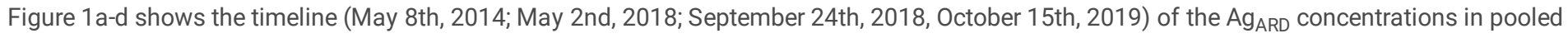

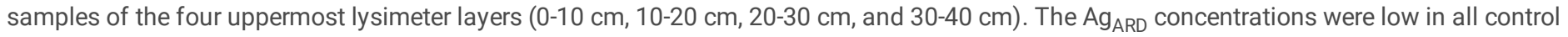
lysimeters ( $\mathrm{L} 1$ and L27, max. $\mathrm{Ag}_{\mathrm{ARD}}=0.05 \pm 0.04 \mathrm{mg} / \mathrm{kg} \mathrm{DMS}, \mathrm{n}=5$, data not shown). Therefore, the measured $\mathrm{Ag}_{\mathrm{ARD}}$ in the other lysimeters can be assigned to the applied $\mathrm{AgNM}$ ( $\mathrm{L} 2$ and L6) and to the applied $\mathrm{AgNO}_{3}(\mathrm{~L} 28)$. The slightly enhanced $\mathrm{Ag}_{\mathrm{ARD}}$ concentrations in the third and fourth layers (Fig. 1C) of L6 can likely be explained by the inaccuracy of the sampling by the Pürckhauer drill. This explanation is supported by the fact that enhanced $\mathrm{Ag}_{\mathrm{ARD}}$ concentrations were not found in the third and fourth layers of L6 in the following sampling campaign (Fig. 1d).

Almost no vertical translocation of the applied AgNM was found during the five years of the long-term experiment, which is in line with other field lysimeter experiments that found high AgNM retention in the plowed Ap horizon with no transport to deeper soil horizons (Makselon et al. 2018). Moreover, the second application of pristine sewage sluge (L6, May 2nd, 2018) and AgNM-spiked sewage sludge (L2, May 2nd, 2018) induced no enhanced vertical translocation of the applied AgNM.

The application of $\mathrm{AgNO}_{3}$-spiked sewage sludge to $\mathrm{L} 28$ (June 6th, 2018) showed no translocation of sludge-applied $\mathrm{Ag}^{+}$to deeper soil layers (Fig. 1b-d). Yang et al. (2020) found Ag migration in an outdoor lysimeter after application of $\mathrm{AgNO}_{3}$-spiked sewage sludge to a depth of $60-80 \mathrm{~cm}$; however, most of the applied Ag also accumulated in the uppermost horizon. Please refer to Section 3.2 and Section 3.5 for further discussions about AgNM and $\mathrm{Ag}^{+}$retention mechanisms and comprehensive conclusions about the environmental fate of AgNM in soil.

The standard deviation of the Ag concentrations in the two uppermost soil horizons remained high during the five years of the experiments. This indicates that despite plowing, AgNM-spiked sludge remains in the area to which it was applied.

\subsection{Silver concentrations in the leachates}


From May 2018 to May 2019, the leachates were sampled from the five lysimeters $(n=42)$ after rainfall events (Fig. 2). The highest release was at a low level (max. $\mathrm{Ag}_{\text {DIN38402 }}=176 \mathrm{ng} / \mathrm{L}$, Lysimeter 2, November 28th, 2018) and was determined in a leachate of L2 with an AgNM concentration of $2+3 \mathrm{mg} \mathrm{AgNM} / \mathrm{kg}$ DMS. The controls showed a very low $\mathrm{Ag}_{\mathrm{DIN} 38402}$ release with arithmetic means of $31 \mathrm{ng} / \mathrm{L}(\mathrm{L} 1, \mathrm{n}=10)$ and $20 \mathrm{ng} / \mathrm{L}(\mathrm{L} 27, \mathrm{n}=7)$. Lysimeter 2 obtained two applications, and L27 obtained one application of unspiked sewage sludge. Therefore, the higher release from L2 compared to $\mathrm{L} 27$ might represent the Ag background in the sewage sludge. According to the Mann-Whitney U test, the distribution of Ag ${ }_{\mathrm{DIN} 38402}$ concentrations released from the control ( $L 1)$ and $L 2$ (arithmetic mean $50 \mathrm{ng} / \mathrm{L}, \mathrm{n}=10$ ) showed significant deviations $(p=0.043)$. $A$ tendency of enhanced Ag concentrations compared to L1 (arithmetic mean $48 \mathrm{ng} / \mathrm{L}, \mathrm{n}=8$ ) was also found for L6; however, deviations in the distribution of the $\mathrm{Ag}_{\mathrm{DIN} 38402}$ concentrations were not significant at the significance level of 0.05 ( $p=0.067$, Mann-Whitney $U$ test). The low and continuous release of $\mathrm{Ag}$ to the leachates is comparable with the results of the previous study that investigated L1, L2 and L6 (Schlich et al. 2017). Other long-term field lysimeter studies are in line with these findings (Durenkamp et al. 2016; Makselon et al. 2018). Moreover, Makselon et al. (2018) showed that AgNM was associated with soil colloids in an undisturbed outdoor lysimeter. The presented $\mathrm{Ag}_{\text {DIN38402 }}$ concentrations do not provide information about the Ag species. However, a preliminary column study with the same soil (Cambisol, Refesol 01A) and AgNM showed that the low released concentration of Ag was associated with soil colloids (Hoppe et al. 2015), which is why the low measured $\mathrm{Ag}_{\mathrm{DIN} 38402}$ is probably associated with soil colloids. The applied concentrations of AgNM ( $\mathrm{L} 2=2+3 \mathrm{mg} \mathrm{AgNM} / \mathrm{kg}$ DMS, L6 = $8 \mathrm{mg} \mathrm{AgNM} / \mathrm{kg}$ DMS) led to a very low release of AgDin38402 (arithmetic mean $\leq 50 \mathrm{ng} / \mathrm{L}$ ). The predicted environmental concentrations in agricultural soils ( $<1 \mu \mathrm{g} \mathrm{Ag} / \mathrm{kg}$ DMS, Gottschalk et al. 2013 ) were far below the applied concentrations in L2 and L6. Given that the experimental design with used soil is transferable to real environmental conditions, a detectable release of AgNM from sewage sludge-treated agricultural soil to leachate and further to groundwater is unlikely.

The distribution of $\mathrm{Ag}_{\mathrm{DIN} 38402}$ concentrations released from the control $(\mathrm{L} 27$ arithmetic mean $20 \mathrm{ng} / \mathrm{L}, n=7)$ and the treatment with $\mathrm{AgNO} \mathrm{O}_{3}(\mathrm{~L} 28$, arithmetic mean $22 \mathrm{ng} / \mathrm{L}, n=7$ ) showed no significant differences according to the Mann-Whitney $\mathrm{U}$ test $(p=1.00)$. Thus, the application of 2 mg $\mathrm{Ag} / \mathrm{kg}$ DMS generated no release of Ag to the leachates. Additionally, Yang et al. (2020) found only a very low release of Ag to the leachates of an outdoor lysimeter after application of $\mathrm{AgNO}_{3}$-spiked sewage sludge. These findings are in line with batch experiments that showed a very high $\mathrm{Ag}$ adsorption capacity in 25 tested soil samples (Hoppe et al. 2014). Therefore, little or no risk of Ag release to leachates is predicted from Agcontaining sewage sludge applied to agricultural soil ( $\leq 2 \mathrm{mg} \mathrm{Ag} / \mathrm{kg} \mathrm{DMS}$ ).

\subsection{Silver concentrations in roots of the crops}

Figure $\mathrm{S} 3$ shows enhanced $\mathrm{Ag}$ concentrations in the $\mathrm{AgNM}$ - and $\mathrm{AgNO}_{3}$-spiked lysimeters $(\mathrm{L} 2, \mathrm{~L} 6, \mathrm{~L} 28)$ in the wheat roots compared to the controls (L1, L27). The Ag concentrations in the two uppermost layers of lysimeter soils (0-20 cm, September 24th, 2018) related to the Ag root concentrations show only slightly enhanced transfer factors for the $\mathrm{AgNM}^{-s p i k e d ~ l y s i m e t e r s ~}(\mathrm{~L} 2=0.8, \mathrm{~L} 6=1.3)$ in contrast to the $\mathrm{AgNO}_{3}$-spiked lysimeter $(\mathrm{L} 28=0.5)$. One can speculate that the roots grow to the areas where the sewage sludge is located to take up nutrients (e.g., nitrogen $(\mathrm{N})$, phosphate $(P)$, sulfur $(S)$ ). Silver nitrate was supposed to be sulfidized to $\mathrm{Ag}_{2} \mathrm{~S}$ by sewage sludge before application to the soil of $\mathrm{L} 28$. Moreover, even bulk $\mathrm{Ag}_{2} \mathrm{~S}$ was found to accumulate in oat roots (Schlich et al. 2018). Therefore, Ag uptake might be an unspecific comechanism induced by nutrient uptake, which might be related to the uptake of $\mathrm{S}$.

The Ag wheat root accumulation in L6, which received only unspiked sewage sludge in 2018, was at the same level as the determined Ag wheat root concentration in 2014 (10 $\pm 0.1 \mathrm{mg} \mathrm{Ag} / \mathrm{kg}$ DMP (2018) vs. $11 \pm 0.8 \mathrm{mg} \mathrm{Ag} / \mathrm{kg} \mathrm{DMP}(2014$, data from Schlich et al. (2017))). This indicates that despite a second sludge application, the mobility of the AgNM applied in 2014 did not change during the end of the experiment in 2019 . Therefore, the applied AgNM represents a low but continuous source for Ag uptake to roots, which suggests that AgNM can be transferred into the food chains up to top level consumers (Ruotolo et al. 2018). However, the transfer from the roots to stems was at a low level for wheat, with no detectable accumulation in the grains (Figure S4). Reduced $\mathrm{AgNM}_{\mathrm{AgNO}}$, and $\mathrm{Ag}_{2} \mathrm{~S}-\mathrm{NM}$ transfer through the root-shoot barrier was formerly found for alfalfa (Medicago sativa L.) by Stegemeier et al. (2015) and oat by Schlich et al. (2018). The root-shoot barrier might depict a limited risk for Ag species to enter the food chain under predicted environmental concentrations in soil ( $<1 \mu \mathrm{g} \mathrm{AgNM/kg} \mathrm{DMS} \mathrm{modeled} \mathrm{by} \mathrm{Gottschalk} \mathrm{et} \mathrm{al.} \mathrm{(2013)).} \mathrm{Figure} 3$ shows increased transfer of $\mathrm{Ag}$ to the skin and body of sugar beets for the AgNM-spiked and $\mathrm{AgNO}_{3}$-spiked lysimeters compared to the controls. In addition, the comparable $\mathrm{Ag}$ beet root concentrations in the $\mathrm{AgNM}$-applied and $\mathrm{AgNO}_{3}$-applied lysimeters support the above discussed hypothesis that Ag uptake might be an unspecific comechanism induced by nutrient uptake. The higher Ag concentration at the root skin suggests that the Ag species might be retained on the surface of the roots. However, information about Ag species and Ag localization within plant roots cannot be provided due to low Ag root concentrations ( $<1 \mathrm{mg} / \mathrm{kg}$ ). Therefore, high-end techniques such as laser ablation (LA) ICP-MS, scanning electron microscopy (SEM), and synchrotron-based X-ray absorption spectroscopy (XAS) could not help to encourage Ag species and localization in root tissues. The mass-bound limitations of these techniques reflect a general problem investigating NM under environmentally relevant concentrations. Despite these limitations, the results indicate that the highest sugar beet root concentrations (1.0 $\pm 0.4 \mathrm{mg} \mathrm{Ag} / \mathrm{kg} \mathrm{AbfKlärV} \mathrm{DMP)} \mathrm{are} \mathrm{below} \mathrm{the}$ highest wheat root concentrations ( $10 \pm 0.1 \mathrm{mg} \mathrm{Ag} / \mathrm{kg} \mathrm{DMP})$. Moreover, the maximal Ag concentrations in the root bodies ( $0.17 \pm 0.05 \mathrm{mg} \mathrm{Ag} / \mathrm{kg}$ DMP) were below the maximal Ag concentrations in the root skin (1.0 $\pm 0.4 \mathrm{mg} \mathrm{Ag} / \mathrm{kg} \mathrm{DMP})$. Considering that the applied AgNM soil concentrations (2-8 $\mathrm{mg} \mathrm{Ag/kg} \mathrm{DMS)} \mathrm{are} \mathrm{above} \mathrm{the} \mathrm{predicted} \mathrm{AgNM} \mathrm{soil} \mathrm{concentrations} \mathrm{(}<1 \mu \mathrm{g} \mathrm{AgNM/kg} \mathrm{DMS} \mathrm{modeled} \mathrm{by} \mathrm{Gottschalk} \mathrm{et} \mathrm{al.} \mathrm{(2013)),} \mathrm{the} \mathrm{risk} \mathrm{of}$ AgNM entering the food chain via sugar beets might be low but cannot be excluded from the presented data.

\subsection{Inhibition of ammonium oxidizing bacteria by silver nanomaterial}


Information on repeated applications of nanomaterials under environmentally relevant conditions is still sparse. In a previous study, we compared the effects of a single and repeated application of AgNM on soil microorganisms and found that after $28 \mathrm{~d}$ of testing, there was no significant difference (Schlich et al. 2016). However, for this study, a standardized test system was used, and AgNM was applied directly to the soil. The most relevant exposure pathway of NM into the environment will be via sewage sludge, which will be applied to agricultural land repeatedly over several years. In sewage sludge, the impact of NMs and their effect on AOB can then be different. Therefore, we performed a second application of AgNM via sewage sludge to an already established outdoor lysimeter experiment (Schlich et al. 2017) to observe a potential increase in the previously observed inhibition of AOB by AgNM.

The second application of AgNM via sewage sludge on L2 was performed to increase the concentration from $2 \mathrm{mg}$ AgNM/kg DMS to $5 \mathrm{mg}$ $\mathrm{AgNM} / \mathrm{kg}$ DMS. Immediately after the 2nd application, there was an increase in the toxicity on AOB (Figure 4). However, this increased toxicity was found in both lysimeters (L2 and L6), although only sewage sludge was added to the soil of L6. The inhibition of L2 increased from below $10 \%$ (March 2018 before the 2nd application) to 49\% in August 2018, while the inhibition of AOB in L6 increased from 50-75\% at the same time.

The results from Kraas et al. (2017) revealed that AgNPs sulfidized under environmentally relevant conditions by passing a WWTP were still bioavailable to soil microorganisms over $140 \mathrm{~d}$. In another long-term study over $90 \mathrm{~d}$, it could be shown that processed AgNM, which had passed a WWTP, had a larger and more persistent effect on the microbial diversity and composition than freshly added AgNM, which was not processed within a WWTP (Forstner et al., 2020). In the experiment of Wang et al. (2016), AgNM applied via sludge to soil contained $87 \% \mathrm{Ag}_{2} \mathrm{~S}$ and $13 \% \mathrm{AgCl}$, whereas in soils amended with control sludge mixed with fresh AgNM or $\mathrm{Ag}_{2} \mathrm{~S}-\mathrm{NM}$, most of the $\mathrm{Ag}$ was present as $\mathrm{Ag} \mathrm{g}_{2} \mathrm{~S}$. Wang et al. (2016) found that in general, $99 \%$ of $\mathrm{AgNM}$ was retained in sludge, and most of it ( $>79 \%)$ was transformed to $\mathrm{Ag}_{2} \mathrm{~S}$, which mainly remained in this state independent of various tested $\mathrm{pH}$ values and chloride concentrations when incubated in soils for up to $400 \mathrm{~d}$. Kraas et al. (2017) concluded that the transformed AgNM was partially amorphous, resulting in $\mathrm{Ag}_{2} \mathrm{~S}$ species with, e.g., a higher solubility, differing from the solubility of crystalline Ag $\mathrm{S}$. Therefore, depending on the environmental conditions, an increased release of $\mathrm{Ag}$ ions from amorphous $\mathrm{Ag}_{2} \mathrm{~S}$ species may explain the impact on AOB observed over $140 \mathrm{~d}$ (Kraas et al., 2017) and in the present outdoor lysimeter experiment. The direct increase in the inhibition of AOB compared to the control (addition of sewage sludge only) after the 2nd application in May 2018 was associated with a strong decrease in the soil pH (4.4-4.5 after application). The decrease in pH from approximately 5.3 (March 2018) to 4.5 could have caused a stronger release of ions from the amorphous Ag species, which then led to a stronger toxicity. After the soil was limed with CaO (November 2018) and the pH increased continuously for several months up to $\mathrm{pH} 6.5$ in May 2019, the inhibition of AOB concurrently decreased. As of August 2019, the pH was in the range of 5 to 5.3 in all lysimeters, resulting in an increase in the inhibition of $A O B$ in L2. The inhibition of AOB found at $5 \mathrm{mg} A g N M / \mathrm{kg} D M S$ in $L 2$, to which a second amount of AgNM was added via sewage sludge, was comparable to the inhibition in L6, in which a concentration of $8 \mathrm{mg}$ AgNM/kg DMS was tested since 2014. A possible influence of soil properties such as $\mathrm{pH}$ on the ion release of AgNM and therefore on their potential toxicity has already been shown (Schlich and Hund-Rinke 2015).

The inhibition in L6 did not fall below $40 \%$ over the entire experimental period. This indicates that the inhibition, which was determined in L6 since 2014, does not appear to be reversible. This, together with the low mobility of AgNM in soils, shows that repeated sewage sludge applications of sewage sludge containing AgNM can cause AgNM accumulation in the soil, leading to increasing inhibition of soil microorganisms.

\subsection{Inhibition of ammonium oxidizing bacteria by silver nitrate}

After application of $\mathrm{AgNO}_{3}$ via sewage sludge to soil, there was initially no inhibition in the first few months from June to September 2018 . The turnover of $\mathrm{AOB}$ in the control was comparable to the turnover measured at the test concentration (Figure S5). After five months, an initial but statistically nonsignificant, inhibition of $13.5 \%$ was found (February 2019 ). When the pH decreased, an inhibition of $37 \%$ in August 2019 and $33 \%$ in October 2019 was detected. In comparison, this inhibition was between the effect of AgNM at concentrations of 2 and 8 mg AgNM/kg DMS. This was probably again due to the variation in pH levels in the soil. Although the lysimeters in this part of the experiment were not limed in November 2018, these lysimeters were refilled in 2018, and the $\mathrm{pH}$ was already in the target range of 5.5 at the beginning of the experiment. However, afterward, the system needed some time to reach equilibrium, and then, as the experiment continued, the pH decreased slightly to 5.0 until the end of the test. In this phase, with a lower $\mathrm{pH}$ value, there was then an increase in toxicity. Another reason for a delayed effect might also be the transformation of $\mathrm{AgNO}_{3}$ in sludge. Wang et al. (2016) found that $\mathrm{AgNO}_{3}$ that was processed in a WWTP or added to sewage sludge had transformed to $\mathrm{Ag}_{2} \mathrm{~S}$ when it was amended to soil. After the soil was amended with $\mathrm{AgNO}_{3}$-spiked sludge, more than $92 \%$ of the total $\mathrm{Ag}$ in the sludge-amended soil was present as $\mathrm{Ag}_{2} \mathrm{~S}$ after one day of incubation, suggesting that there was a fast transformation to $\mathrm{Ag}_{2} \mathrm{~S}$. In a study with soil only, it could be shown that when soils varying in $\mathrm{pH}$ were freshly spiked with $\mathrm{AgNO}_{3}$, acidic conditions favored the formation of $\mathrm{AgCl}$, whereas $\mathrm{Ag}_{2} \mathrm{~S}$ dominated in neutral or alkaline conditions (Sekine et al., 2015). Therefore, it might be possible that immediately after the transformation of $\mathrm{AgNO}_{3}$ to $\mathrm{Ag}_{2} \mathrm{~S}, \mathrm{Ag}$ was less toxic due to a reduced release of $\mathrm{Ag}$ ions. However, with changing environmental conditions, a decrease in the $\mathrm{pH}$, which likely accelerated the ion release, caused more pronounced toxic effects on AOB.

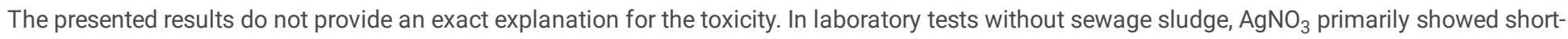
term toxicity with direct effects after application (Schlich et al. 2013). However, $\mathrm{AgNO}_{3}$ showed a comparable effect to $\mathrm{AgNM}$ in this long-term 
outdoor lysimeter study. This suggests that a transformation to $\mathrm{Ag}_{2} \mathrm{~S}$, as found by several groups, also occurred for $\mathrm{AgNO}_{3}$, resulting in long-term toxicity.

\subsection{Overall discusion}

The neglectable Ag transfer to the deeper soil layers (Section 3.1) and the neglectable transfer from soil to leachates (Section 3.2) indicate that the sludge-applied $\mathrm{AgNM}$ and $\mathrm{AgNO}_{3}$ remained nearly immobile in the soil. These findings are in line with the common state of knowledge that soil is a large sink for AgNM (e.g., Cornelis et al. 2014) and other NMs (Hoppe et al. 2019). This study confirmed the state of knowledge for the first time over a period of five years and twofold sewage sludge application. The same AgNM and soil tested in this study were previously tested in short-term column experiments and showed a very low release of Ag associated with natural soil colloids (Hoppe et al. 2015). Despite different experimental designs (application, duration), the laboratory column experiments and outdoor lysimeter experiments led to the same conclusion that soils are a large sink for AgNM. In the case of sludge-applied $\mathrm{AgNM}$ and $\mathrm{AgNO}_{3}$, short-term laboratory experiments appeared to be sufficient to estimate the $\mathrm{Ag}$ release that occurred in the presented long-term field experiments. However, the application to sewage sludge and subsequent long-term incorporation into an outdoor lysimeter represents a more realistic environmental pathway and is mandatory to assess the uptake of Ag species to crops. Silver uptake from AgNM-spiked and $\mathrm{AgNO}_{3}$-spiked soils was determined for wheat and sugar beets (Section 3.3). Previously, Stegemeier et al. (2015) conducted hydroponic exposure of alfalfa and indicated $\mathrm{AgNM}, \mathrm{Ag}_{2} \mathrm{~S}-\mathrm{NM}$, and $\mathrm{AgNO}_{3}$ accumulation along the apoplasts of the roots but only a low translocation to the shoot system. Root accumulation was also found for oat after exposure to different $\mathrm{Ag}$ species (AgNM, $\mathrm{Ag} \mathrm{S}_{2} \mathrm{~S}-\mathrm{NM}$, $\mathrm{AgNO}_{3}$ ) spiked into soil by sewage sludge (Schlich et al. 2018). Root uptake suggests that AgNM can be transferred into food chains up to top-level consumers (Ruotolo et al. 2018). This assumption is not falsifiable from the presented findings, although the measured uptake from AgNM-spiked and $\mathrm{AgNO}_{3}$-spiked lysimeters was at a low level, and only limited transfer through the root-shoot barrier was identified.

Spurgeon et al. (2020) addressed the urgent need for long-term studies on the toxicity of NM. The inhibition of AOB (Sections 3.4 and 3.5) and the high retention of AgNM applied to soil via sewage sludge led to increasing inhibition of soil microorganisms. Even though the investigated Ag concentrations of $8 \mathrm{mg} / \mathrm{kg}$ DMS seem very high in relation to predicted environmental concentrations, repeated application of sewage sludge over a long period of time, even when considering the presence of other NMs (mixed toxicity), may lead to an adverse effect on soil microorganisms. Grün and Emmerling (2018) observed an effect on autotrophic ammonia oxidation (nitrification) and organic carbon transformation in soils at a very low AgNM concentration of $0.01 \mathrm{mg} \mathrm{AgNM} / \mathrm{kg}$ DMS. Taking into account that the predicted environmental concentrations (<1 $\mu \mathrm{g}$ AgNM/kg DMS modeled by Gottschalk et al. (2013)) are far below the applied AgNM concentrations in this study, the potential risk of AgNM entering the groundwater or affecting $A O B$ is nearly negligible. However, a risk for the food chain cannot completely be excluded from the presented data because of the measured $\mathrm{AgNM}$ and $\mathrm{AgNO}_{3}$ plant uptake. The localization and speciation of AgNM in the plant tissue was not possible because of the lack of analytical techniques to determine NM under predicted environmental concentrations (Nowack et al. 2015). To further the debate on whether NM might compromise the food chain, further technical developments are necessary.

\section{Conclusion}

Almost no vertical translocation or release of $\mathrm{AgNM}$ and $\mathrm{AgNO}_{3}$ to the percolating water was detected, even though the applied concentrations were fare above the PEC. The second application of AgNM-spiked and pure sewage sludge to the existing lysimeters showed no enhanced remobilization of $\mathrm{AgNM}$. Therefore, agricultural soils are a large sink for $\mathrm{AgNM}$ and $\mathrm{AgNO}_{3}$ applied by sewage sludge. $\mathrm{However}, \mathrm{AgNM}$ and $\mathrm{AgNO} \mathrm{H}_{3}$ application resulted in comparable inhibition of $A O B$ during the entire field lysimeter experiment. Moreover, an increasing inhibition of $A O B$ was identified with repeated application via sewage sludge, which clearly indicates an accumulation effect. Due to the repeated application of sludge over many years, the soil microbial community might be exposed to a high risk.

In summary, the results indicate that $\mathrm{AgNM}$ and $\mathrm{AgNO}_{3}$ will partly be remobilized in the rhizosphere and translocated to the roots of wheat and sugar beet. Hence, AgNM will be bioavailable (AOB, crops) over several years, although root accumulation is low. However, the applied AgNM concentrations were above the predicted environmental concentrations, which explains why the observed root uptake might be neglectable in agricultural practice.

\section{Declarations}

\section{Acknowledgments}

The authors would like to thank Elke Wargenau, Christiane Kamphuis, Sarah Fliegel, Micheal Fischer, Ruben Schlinkert, Theo Görtz and Dennis Hennemann for the laboratory work.

\section{Authors contributions}


M. Hoppe, K. Schlich, J. Köser and K. Hund-Rinke designed the research; K. Schlich and M. Hoppe performed the experiments; M. Hoppe and K. Schlich wrote the first draft; J. Köser and K. Hund-Rinke reviewed the paper. M. Hoppe edited all paper drafts.

\section{Authors information}

Federal Institute for Geosciences and Natural Resources

Martin Hoppe \& Jan Köser

Stilleweg 2, Hannover, 30655, Germany

Fraunhofer Institute for Molecular Biology and Applied Ecology

Karsten Schlich \& Kerstin Hund-Rinke

Auf dem Aberg 1, Schmallenberg, 57392, Germany

\section{Corresponding author}

Correspondence to Martin Hoppe (martin.hoppe@bgr.de).

\section{Conflict of interest}

The authors declare that they have no known competing financial interests or personal relationships that could have appeared to have influenced the work reported in this paper.

\section{Consent to publish}

All authors vouch that the work has not been published elsewhere, completely, in part, or any other form, and that the manuscript has not been submitted to another journal. The authors approve the manuscript and give their consent for submission and publication.

\section{Ethical approval}

Materials used in this study were common plants, and this study does not involve human participants or animals performed by any of the authors.

\section{Plant reproducibility}

The authors guarantee the reproducibility of experimental results.

\section{Funding}

This study was funded by the German Federal Ministry for Economic Affairs and Energy.

\section{References}

1. AbfKlärV (1992) Deutsche Klärschlammverordnung, 15. April 1992 (BGBI. I S. 912). https://www.bgbl.de/xaver/bgbl/start.xav? start=//*\%5B@attr_id=\%27bgbl192s0912.pdf\%27\%5D\#_bgbl_\%2F\%2F*\%5B\%40attr_id\%3D\%27bgbl192s0912.pdf\%27\%5D_1629735325928

2. Ad-hoc-AG Boden (2006) Bodenkundliche Kartieranleitung. 5. verbesserte und erweiterte Auflage. BGR in Zusammenarbeit mit den Staatlichen Geologischen Diensten (ed). Schweizerbart Science Publishers, Stuttgart, p 438. https://www.schweizerbart.de/publications/detail/isbn/9783510959204/Bodenkundliche_Kartieranleitung_5_Aufl

3. Benn T, Cavanagh B, Hristovski K, Posner JD, Westerhoff P (2010) The Release of Nanosilver from Consumer Products Used in the Home. J Environ Qual 39:1875-1882. https://doi.org/10.2134/jeq2009.0363

4. Bundschuh M, Filser J, Lüderwald S et al (2018) Nanoparticles in the environment: where do we come from, where do we go to? Environmental Sciences Europe 30:6. https://doi.org/10.1186/s12302-018-0132-6 
5. Cornelis G, Hund-Rinke K, Kuhlbusch T, van den Brink N, Nickel C (2014) Fate and Bioavailability of Engineered Nanoparticles in Soils: A Review. Critical Reviews in Environmental Science Technology 44:2720-2764. https://doi.org/10.1080/10643389.2013.829767

6. Courtois P, Rorat A, Lemiere S, Guyoneaud R, Attard E, Levard C, Vandenbulcke F (2019) Ecotoxicology of silver nanoparticles and their derivatives introduced in soil with or without sewage sludge: A review of effects on microorganisms, plants and animals. Environ Pollut 253:578-598. https://doi.org/10.1016/j.envpol.2019.07.053

7. DIN EN 16174 (2012) Sludge, treated biowaste and soil - Digestion of aqua regia soluble fractions of elements; German version EN 16174: 2012. Beuth Verlag, Berlin. https://www.beuth.de/de/norm/din-en-16174/148093733

8. Durenkamp M, Pawlett M, Ritz K, Harris JA, Neal AL, McGrath SP (2016) Nanoparticles within \{WWTP\} sludges have minimal impact on leachate quality and soil microbial community structure and function. Environ Pollut 211:399-405. http://dx.doi.org/10.1016/j.envpol.2015.12.063

9. Forstner C, Orton TG, Wang P, Kopittke PM, Dennis PG (2020) Wastewater Treatment Processing of Silver Nanoparticles Strongly Influences Their Effects on Soil Microbial Diversity. Environmental Science Technology 54:13538-13547. https://doi.org/10.1021/acs.est.0c01312

10. Gardea-Torresdey JL, Rico CM, White JC (2014) Trophic Transfer, Transformation, and Impact of Engineered Nanomaterials in Terrestrial Environments. Environmental Science Technology 48:2526-2540. https://doi.org/10.1021/es4050665

11. Gottschalk F, Sun T, Nowack B (2013) Environmental concentrations of engineered nanomaterials: Review of modeling and analytical studies. Environ Pollut 181:287-300. http://dx.doi.org/10.1016/j.envpol.2013.06.003

12. Grün AL, Emmerling C (2018) Long-term effects of environmentally relevant concentrations of silver nanoparticles on major soil bacterial phyla of a loamy soil. Environmental Sciences Europe 30:31. https://doi.org/10.1186/s12302-018-0160-2

13. Hänsch M, Emmerling C (2010) Effects of silver nanoparticles on the microbiota and enzyme activity in soil. J Plant Nutr Soil Sci 173:554-558. https://doi.org/10.1002/jpln.200900358

14. Hoppe M, Mikutta R, Utermann J, Duijnisveld W, Guggenberger G (2014) Retention of Sterically and Electrosterically Stabilized Silver Nanoparticles in Soils. Environmental Science Technology 48:12628-12635. https://doi.org/10.1021/es5026189

15. Hoppe M, Mikutta R, Utermann J, Duijnisveld W, Kaufhold S, Stange CF, Guggenberger G (2015) Remobilization of sterically stabilized silver nanoparticles from farmland soils determined by column leaching. Eur J Soil Sci, 66, https://onlinelibrary.wiley.com/doi/10.1111/ejss.12270

16. Hoppe M, Schlich K, Wielinski J, Köser J, Rückamp D, Kaegi R, Hund-Rinke K (2019) Long-term outdoor lysimeter study with cerium dioxide nanomaterial. Nanolmpact 14:100170. https://doi.org/10.1016/j.impact.2019.100170

17. ISO Guideline 15685 (2012) Soil quality - Determination of potential nitrification and inhibition of nitrification - Rapid test by ammonium oxidation, in: International Organization for Standardization (Ed.), Geneva, Switzerland. https://www.iso.org/standard/53530.html

18. Kaegi R, Voegelin A, Ort C et al (2013) Fate and transformation of silver nanoparticles in urban wastewater systems. Water Res 47:3866-3877. https://doi.org/10.1016/j.watres.2012.11.060

19. Klein CL, Comero S, Stahlmecke J et al (2011) NM-Series of representative manufactured nanomaterials NM-300 Silver characterisation, stability, homogeneity. Tech. rep., JRC. https://doi.org/10.2788/23079

20. Kraas M, Schlich K, Knopf B, Wege F, Kägi R, Terytze K, Hund-Rinke K (2017) Long-term effects of sulfidized silver nanoparticles in sewage sludge on soil microflora. Environ Toxicol Chem 36:3305-3313. https://doi.org/10.1002/etc.3904

21. Levard C, Hotze EM, Lowry GV, Brown GE (2012) Environmental Transformations of Silver Nanoparticles: Impact on Stability and Toxicity. Environmental Science Technology 46:6900-6914. https://doi.org/10.1021/es2037405

22. Lowry G, Espinasse BP, Badireddy AR et al (2012) Long-Term Transformation and Fate of Manufactured Ag Nanoparticles in a Simulated Large Scale Freshwater Emergent Wetland. Environmental Science Technology 46:7027-7036. https://doi.org/10.1021/es204608d

23. Makselon J, Siebers N, Meier F, Vereecken H, Klumpp E (2018) Role of rain intensity and soil colloids in the retention of surfactant-stabilized silver nanoparticles in soil. Environ Pollut 238:1027-1034. https://doi.org/10.1016/j.envpol.2018.02.025

24. Nowack B, Baalousha M, Bornhöft N et al (2015) Progress towards the validation of modeled environmental concentrations of engineered nanomaterials by analytical measurements. Environ Sci: Nano 2(5):421-428.

https://pubs.rsc.org/en/content/articlelanding/2015/EN/C5EN00100E

25. OECD Guideline 216 (2000) OECD Guideline for the testing of chemicals. Test No. 216: Soil Microorganisms: Nitrogen Transformation Test. Organisation for Economic Co-operation and Development, Paris. https://www.oecd.org/chemicalsafety/risk-assessment/1948317.pdf

26. OECD Guideline 217 (2000) OECD Guideline for the Testing of Chemicals. Test Guideline 217: Soil Microorganisms: Carbon Transformation Test. Organisation for Economic Co-operation and Development, Paris. https://www.oecd.org/chemicalsafety/risk-assessment/1948325.pdf

27. Pan B, Xing B (2012) Applications and implications of manufactured nanoparticles in soils: a review. Eur J Soil Sci, $63,437-456$. https://onlinelibrary.wiley.com/doi/10.1111/j.1365-2389.2012.01475.x

28. Ruotolo R, Maestri E, Pagano L, Marmiroli M, White JC, Marmiroli N (2018) Plant Response to Metal-Containing Engineered Nanomaterials: An Omics-Based Perspective. Environmental Science Technology 52:2451-2467. https://pubs.acs.org/doi/abs/10.1021/acs.est.7b04121 
29. Schlich K, Klawonn T, Terytze K, Hund-Rinke K (2013) Hazard assessment of a silver nanoparticle in soil applied via sewage sludge. Environ Sci Eur 25:17. https://doi.org/10.1186/2190-4715-25-17

30. Schlich K, Hund-Rinke K (2015) Influence of soil properties on the effect of silver nanomaterials on microbial activity in five soils. Environ Pollut 196:321-330. https://doi.org/10.1016/j.envpol.2014.10.021

31. Schlich K, Beule L, Hund-Rinke K (2016) Single versus repeated applications of CuO and Ag nanomaterials and their effect on soil microflora. Environ Pollut 215:322-330. DOI:10.1016/j.envpol.2016.05.028

32. Schlich K, Hoppe M, Kraas M, Fries E, Hund-Rinke K (2017) Ecotoxicity and fate of a silver nanomaterial in an outdoor lysimeter study. Ecotoxicology. https://doi.org/10.1007/s10646-017-1805-4

33. Schlich K, Hoppe M, Kraas M, Schubert J, Chanana M, Hund-Rinke K (2018) Long-term effects of three different silver sulfide nanomaterials, silver nitrate and bulk silver sulfide on soil microorganisms and plants. Environ Pollut 242:1850-1859. https://doi.org/10.1016/j.envpol.2018.07.082

34. Sekine R, Brunetti G, Donner E et al (2015) Speciation and Lability of Ag-, AgCl-, and Ag2S-Nanoparticles in Soil Determined by X-ray Absorption Spectroscopy and Diffusive Gradients in Thin Films. Environmental Science Technology 49:897-905. https://doi.org/10.1021/es504229h

35. Spurgeon DJ, Lahive E, Schultz CL (2020) Nanomaterial Transformations in the Environment: Effects of Changing Exposure Forms on Bioaccumulation and Toxicity. Small 16:2000618. https://doi.org/10.1002/smll.202000618

36. Stegemeier JP, Schwab F, Colman BP et al (2015) Speciation Matters: Bioavailability of Silver and Silver Sulfide Nanoparticles to Alfalfa (Medicago sativa). Environmental Science Technology, 49, https://pubs.acs.org/doi/10.1021/acs.est.5b01147

37. Tourinho PS, van Gestel CA, Lofts S, Svendsen C, Soares AM, Loureiro S (2012) Metal-based nanoparticles in soil: Fate, behavior, and effects on soil invertebrates. Environ Toxicol Chem 31:1679-1692. https://doi.org/10.1002/etc.1880

38. Wang P, Menzies NM, Dennis PG et al (2016) Silver Nanoparticles Entering Soils via the Wastewater-Sludge-Soil Pathway Pose Low Risk to Plants but Elevated Cl Concentrations Increase Ag Bioavailability. Environmental Science Technology 50:8274-8281. https://doi.org/10.1021/acs.est.6b01180

39. Wang P, Lombi E, Menzies NW, Zhao FJ, Kopittke PM (2018) Engineered silver nanoparticles in terrestrial environments: a meta-analysis shows that the overall environmental risk is small. Environ Sci: Nano 5(11):2531-2544. https://pubs.rsc.org/en/content/articlelanding/2018/EN/C8EN00486B

40. Westerhoff P, Nowack B (2013) Searching for Global Descriptors of Engineered Nanomaterial Fate and Transport in the Environment. Acc Chem Res 46:844-853. https://doi.org/10.1021/ar300030n

41. Yang L, Li S, Wu L, Ma Y, Christie P, Luo Y (2020) A field study of the fate of biosolid-borne silver in the soil-crop system. Environ Pollut 259:113834. https://doi.org/10.1016/j.envpol.2019.113834

\section{Figures}



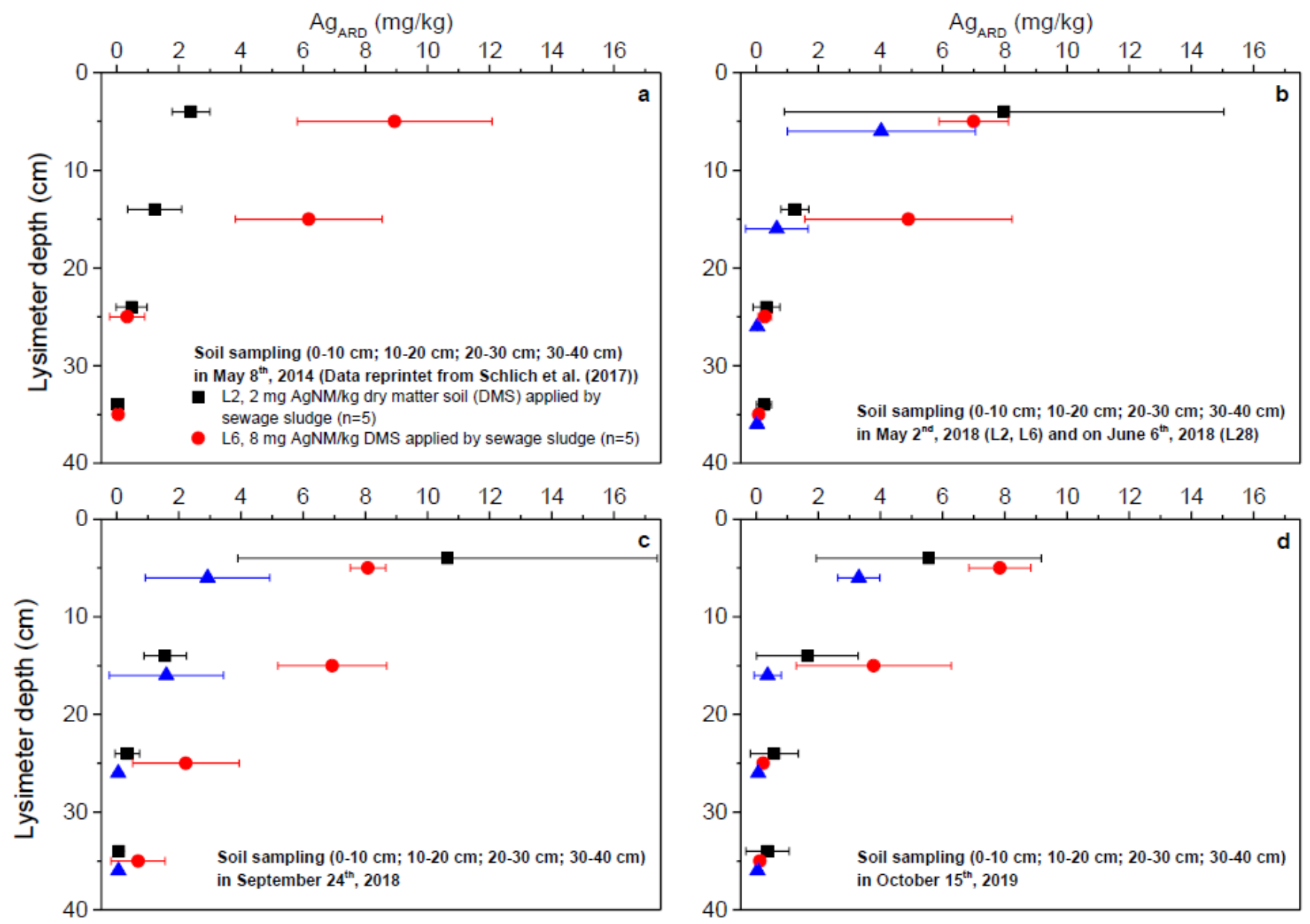

- $\mathrm{L} 2,2+3 \mathrm{mg}$ AgNM/kg DMS applied by sewage sludge $(\mathrm{n}=5)$

- L6, $8+0 \mathrm{mg} \mathrm{AgNM} / \mathrm{kg}$ DMS applied by sewage sludge $(n=5)$

- L28, $2 \mathrm{mg} \mathrm{Ag} / \mathrm{kg}$ DMS applied as $\mathrm{AgNO}_{3}$ by sewage sludge $(\mathrm{n}=5)^{*}$

${ }^{*} \mathrm{n}=4$ for $0-10 \mathrm{~cm}$ and $10-20 \mathrm{~cm}, \mathrm{n}=3$ for $20-30 \mathrm{~cm}$ and $30-40 \mathrm{~cm}$ at sampling campaign in October $15^{\mathrm{th}}, 2019$

Figure 1

Total Ag concentrations after aqua regia digestion (ARD) in the pooled samples of the four uppermost lysimeter layers (0-10 $\mathrm{cm}, 10-20 \mathrm{~cm}, 20-30$ $\mathrm{cm}, 30-40 \mathrm{~cm}$ ). Silver nanomaterial (AgNM, OECD standard, NM-300K) was applied using sewage sludge to the two uppermost layers (0-10 cm, 10$20 \mathrm{~cm}$ ) in 2014 (lysimeter 2 (L2) and lysimeter 6 (L6)). In 2018, an additional application of AgNM (L2) and silver nitrate (AgNO3, lysimeter 28 (L28)) was conducted by sewage sludge. Error bars represent the standard deviation. Data in Fig. 1a are reprinted from Schlich et al. (2017). Control lysimeter 1 (L1) received pristine sewage sludge in 2014 and 2018, and control lysimeter 27 (L27) received pristine sewage sludge in 2018. The Ag concentrations in the controls (data not shown) were below $0.05 \mathrm{mg} \mathrm{Ag} / \mathrm{kg}$ dry matter soil (DMS) in all layers during the five years of the experiment. 


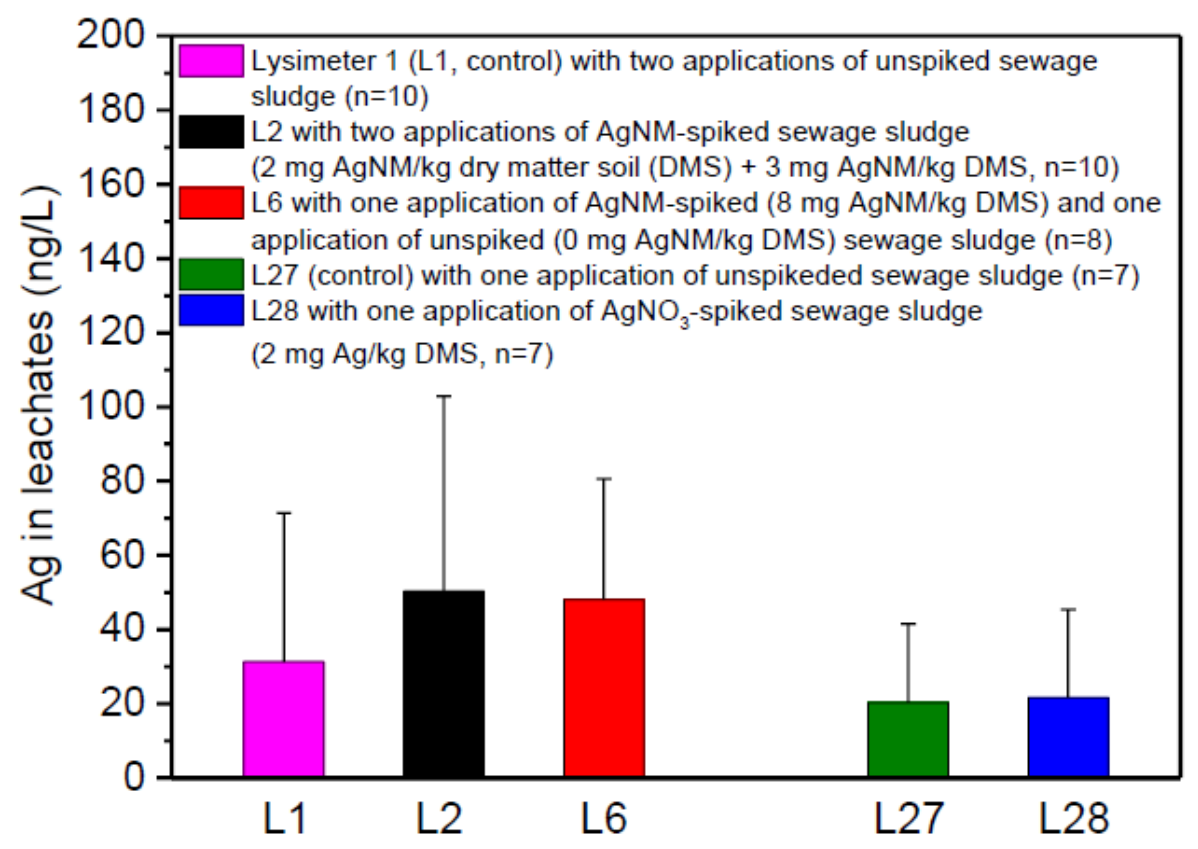

Figure 2

Silver concentrations (AgDIN38402) in the leachates of the lysimeters measured between May 18th, 2018 and May 13th, 2019. Error bars represent the standard deviation of $\geq 7$ replicates. According to the Mann-Whitney $U$ test null hypothesis (H0: The distribution of Ag concentrations are equal between the control groups (L1, L27) and the Ag-spiked lysimeters (L2, L6, L28) was only declined for L1 vs. L2 ( $p<0.05)$.

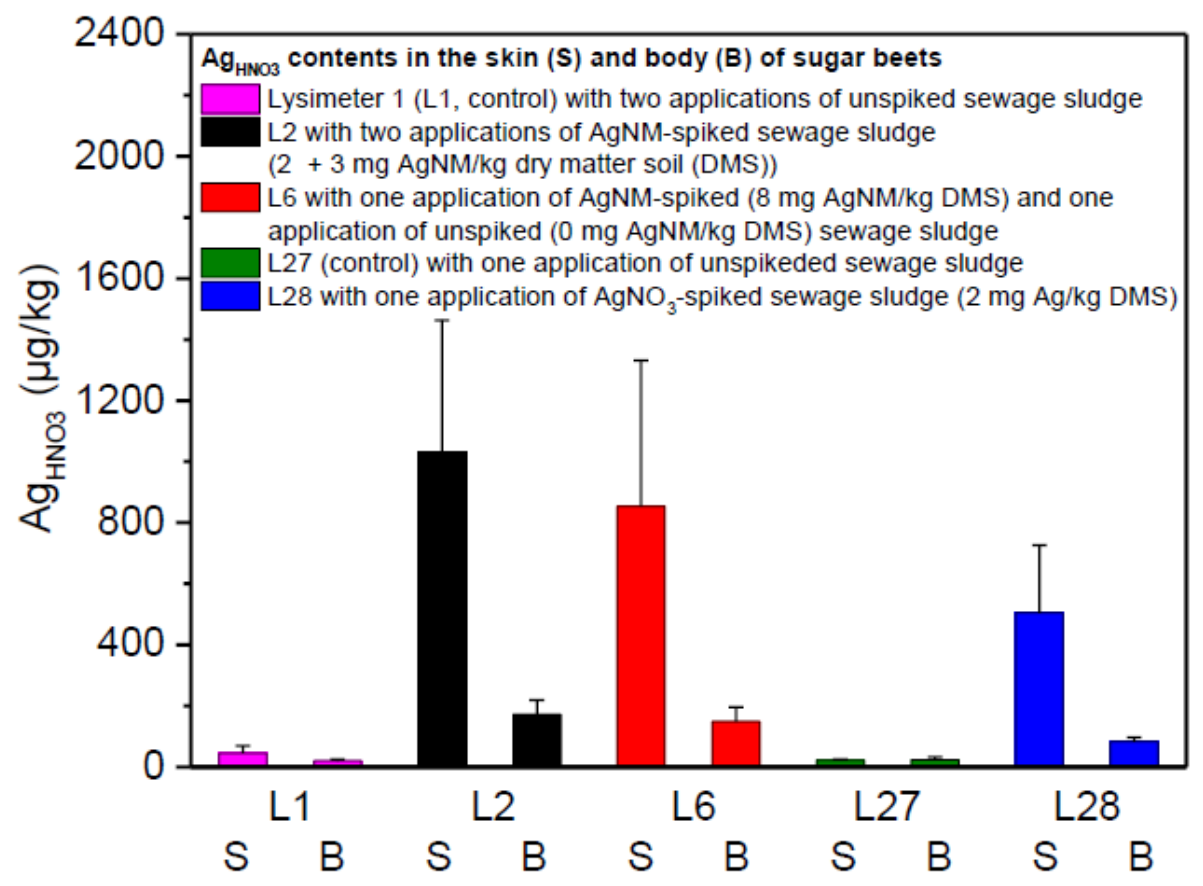

Figure 3

Silver (AgHNO3) concentrations in the skin (S) and body (b) of sugar beet roots (sampling September 24th, 2019). Lysimeters 1 (L1) and L27 represent the controls ( $0.05 \mathrm{mg} \mathrm{Ag} / \mathrm{kg}$ dry matter soil (DMS)), L2 and L6 represent the AgNM-spiked lysimeters (L2 = $2+3 \mathrm{mg}$ AgNM/kg DMS, L6 = $8 \mathrm{mg} \mathrm{AgNM} / \mathrm{kg} \mathrm{DMS}$ ), and L28 represents the AgNO3-spiked lysimeter ( $228=2 \mathrm{mg} \mathrm{AgNM} / \mathrm{kg} \mathrm{DMS}$ ). Error bars show the standard deviation of three replicates. 


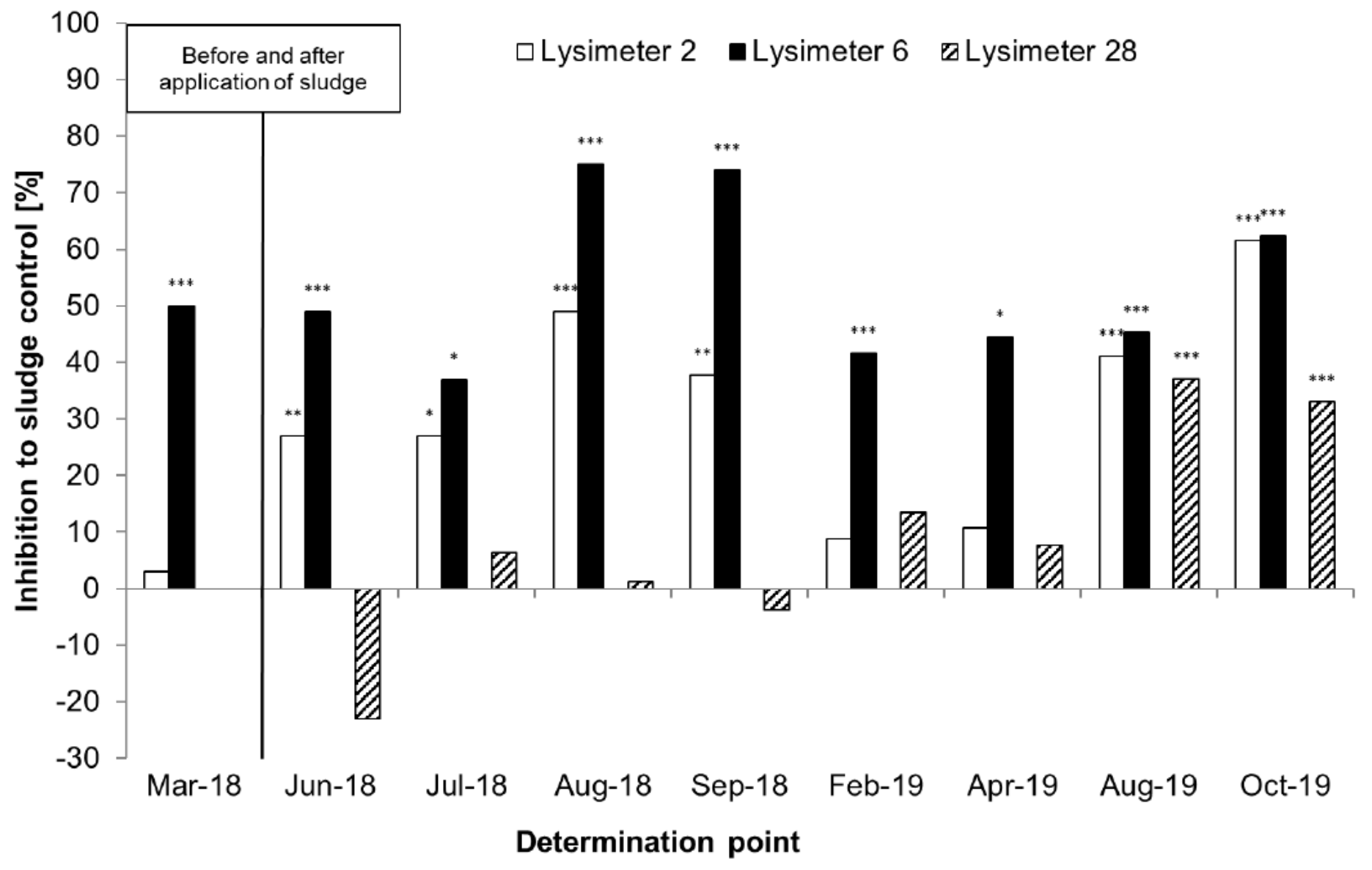

Figure 4

Inhibition of ammonium-oxidizing bacteria (AOB) due to AgNM (lysimeter 2, lysimeter 6) or AgNO3 (lysimeter 28) applied to soil via sewage sludge over the complete course of the outdoor lysimeter study from March 2018 (before application) until October 2019 (end of experiment). In March 2018, L2 and L6 had measured concentrations of 2 and $8 \mathrm{mg} \mathrm{AgNM} / \mathrm{kg}$ dry matter soil (DMS). Afterward, the 2nd application was performed the concentrations at L2 was $2+3 \mathrm{mg} \mathrm{AgNM} / \mathrm{kg}$ DMS, and $8 \mathrm{mg} \mathrm{AgNM} / \mathrm{kg} \mathrm{DMS}$ at L6. L28 had an Ag concentration of $2 \mathrm{mg} \mathrm{Ag} / \mathrm{kg}$ DMS. Statistics: Student's t-test, one sided, ${ }^{*} \mathrm{p}<0.05 ;{ }^{* \star} \mathrm{p}<0.01 ;{ }^{* \star *} \mathrm{p}<0.001$.

\section{Supplementary Files}

This is a list of supplementary files associated with this preprint. Click to download.

- AppendixA.docx 